\title{
Australian consumers' perceptions of environmental and agricultural threats: The associations of demographic and of psychographic variables
}

\author{
Anthony Worsley*, Wei Wang, Stacey Ridley \\ Centre for Physical Activity and Nutrition Research, Deakin University
}

Email address:

tonyw@deakin.edu.au (A. Worsley)

\section{To cite this article:}

Anthony Worsley, Wei Wang, Stacey Ridley. Australian Consumers' Perceptions of Environmental and Agricultural Threats: The Associations of Demographic and of Psychographic Variables. American Journal of Environmental Protection. Vol. 3, No. 1, 2014, pp. 10-18. doi: 10.11648/j.ajep.20140301.12

\begin{abstract}
Currently little is known about the ways consumers perceive the issues and threats facing the agricultural sector. Understanding of the sector among the general community is important for its continued economic, social and environmental sustainability. Therefore we conducted an on-line survey among 1026 respondents drawn from each State and Territory in Australia. Initial examination of the responses showed most respondents held protectionist views about issues such as coal seam gas mining, imported food products and subsidies for agriculture and were aware of environmental and other threats. There were few city-country differences. Tertiary educated respondents tended to hold firmer opinions and more laissez-faire views than other respondents. Confirmatory factor analysis revealed two threat dimensions, one relating to threats to soil quality, the other about pollution and the survival of native animals. Stepwise multiple regression analyses of these dimensions showed that universalist values and trust in independent scientific information sources were positively associated with threat perceptions. The findings suggest that consumers generally are aware of agricultural issues, particularly those who hold strong universalist values. The respondents' views of policy issues diverge in several respects from prevailing views of economic orthodoxy. Future consumer communication and research opportunities are discussed.
\end{abstract}

Keywords: Agriculture, Environment, Consumers, Survey, Australia

\section{Introduction}

Australian agriculture faces many challenges [1] These range from threats to its economic sustainability and survival in a competitive international trading environment [1], through to its continuing ability to provide the Australian population with access to healthy foods and to maintain the environmental sustainability on which it depends [2-8]. The problems it faces are not confined to Australia and they are part of a more general questioning of the state of the global food system $[9,10]$.

Whilst the sector faces a range of challenges it is unclear if the broader Australian community appreciates or understands them. Such understanding is essential if the sector is to gain the political, social and economic resources to meet its current challenges. However, little is known about the ways Australians understand the challenges faced by the agricultural sector. Although several studies have examined American and British consumers' views of agriculture and related topics (e.g., relatively few studies have examined Australian consumers' views of the sector. One qualitative study of 26 respondents found high levels of interest among consumers in agricultural production processes[11]. Another, showed major divergence of opinion about human impacts on climate, primary producers being far more skeptical than urban consumers [12].

Whilst these studies suggest that consumers may be interested in the sector, much remains to be understood about lay people's understanding of farming and the challenges farmers face. Therefore the main aim of this study was to ask a sample of Australian consumers about these issues.

\section{Likely Predictors of Concern about Threats}

We hypothesized that there may be several factors which may predict respondents' perceptions of the challenges facing farming in Australia. These included both 
demographic and psychographic factors. Among the demographics relationships we expected that:

Women might be more aware of environmental threats to farming since earlier work has shown that more women than men are interested in environmental issues [13] and in food issues than men [14-16].

Older people may be more aware of the challenges faced by farmers than younger people in view of earlier work which has shown that older people are more aware of a range of food and health concerns [15-18].

We also hypothesized that tertiary educated respondents would be less aware of agricultural issues, and less supportive of the sector, than non graduates. Our previous work on food concerns and community support for food and health policies, has shown that the tertiary educated are less concerned about most food (and other) issues than less educated people $[19,20]$. Further, this group were also less supportive of government interventions in the provision of food at school [21].

There are anecdotal claims that "“city" people are less supportive of agriculture than "country" people", perhaps because of their greater distance from farming activities. Therefore we wanted to examine whether there are any differences in the ways people living in metropolitan and regional areas understand the challenges facing the sector. We hypothesized that urban residents would be less supportive of farming than rural or regional residents.

The main psychographic variable which we expected to be related to the appreciation of many of the environmental threats facing agriculture were universalism values (values being defined as guiding principles in people's lives [22]). These are communitarian values relating to benevolence, harmony and community and environmental wellbeing. In Schwartz's circumplex model of human values universalist values are in opposition to self oriented values such as achievement and hedonism [22]. In our previous work we have shown that Universalism is linked to healthy dietary habits [23-25] and support for pro-environmental food policies [26]. We hypothesized that the higher a person's universalism values, the greater would be their awareness of threats to agriculture, especially environmental threats.

One set of beliefs measured in this study was respondents' degree of approval of farmers' role performance for example, their stewardship of the environment and their care of animals (Appendix 1). We expected that the more highly respondents' evaluated farmers' role performance the less would be their perceptions of the threats facing agriculture because competent farmers might be seen as more able to deal with these challenges.

We were also able to assess the respondents' trust in the information supplied by twenty eight prominent Australian organizations (Appendix 2). Confirmatory factor analysis showed that these formed three groupings: independent information sources (like state departments of primary industries and health), peak industry bodies (like the National Farmers' Federation) and retailers (reported elsewhere). Respondents' scores on each of these three factors were used as predictor variables in multiple regression analyses of the threat factors, described below. We expected trust in information from independent and industry peak bodies to be associated with greater awareness of the threats.

\section{Methods}

\subsection{Sampling and Procedure}

The Agriculture, the Environment and Food questionnaire was an internet-based survey conducted nationally during August 2012. It was designed to determine Australian adults' knowledge and perceptions of a number of issues relating to Australian agriculture. The survey was conducted by Global Market Insights (GMI), who invited potential respondents from the company's database of registered adults living in Australia to participate through a link to the survey. Quota sampling was used to ensure that the ages, gender, educational status and state of residence of the respondents represented the proportions found in the Australian population. One thousand and twenty six respondents took part in the survey. The order of items within lists was randomized for each respondent in order to minimize order and fatigue effects.

The study was approved by the Deakin University Faculty of Health Human Ethics Committee (HEAG H47-2012).

\subsection{The Questionnaire}

The questionnaire was divided into several sections which included questions about the respondents' views of farming issues and threats facing the sector, particularly environmental threats (using five point importance scales); attitudes towards farmers' performance of key roles (Appendix 1; Cronbach's alpha $=0.914$ ); issues that should be addressed now and in the future; and the trustworthiness of agricultural and food information disseminated by 28 organizations (Appendix 2). In addition information was gathered about the respondent' ages, gender, educational background (left high school before year 11, completed high school, technical or trade qualifications, university education) and postcode. Postcode to Remoteness data was downloaded from the Australian Bureau of Statistics (ABS) website. The postcodes were recoded into two categories: Metropolitan (major cities only, 686 respondents) and Regional (inner and outer regional Australia, remote and very remote Australia, 340 respondents). The respondents' Universalist values were assessed through administration of six items from the Schwartz Personal Values Inventory which we have used in previous studies [22-25].

\subsection{Data Analysis}

Response frequencies for each of the items were calculated using the SPSS (version 20) FREQUENCIES program. The confirmatory factor analyses of the threat ratings and the trustworthiness of information sources were conducted in 
Mplus 7 [27]. Robust Maximum likelihood (MLR) estimation was used. Model evaluations were examined by chi-square statistics and accompanying significance tests. Goodness-of-fit indices reported are the Standardized Root-Mean-Square Residual (SRMR), Root Mean Square Error of Approximation (RMSEA), Tucker-Lewis index (TLI), and Comparative fit index (CFI) [28]. When the models were considered to fit the data well, the following criteria were met: $\chi^{2}$ probability $p>.05, \mathrm{SRMR}<.05$, RMESA $<.05$, TLI $>.95$, and CFI $>$.95. Multiple regression was run in Mplus on each of the threat factors using the demographic variables, universalist values and information trustworthiness factors as predictor variables.

\section{Results}

\subsection{Characteristics of the Respondents}

Over one thousand adults (1026) drawn from across Australia took part in the survey. Just over half were women $(51.6 \%, \mathrm{n}=529), 34.1 \%(\mathrm{n}=350)$ were tertiary graduates, $30.7 \%(n=307)$ were TAFE or technically qualified and the remainder had high school education only. Just over one third $(33.1 \%, \mathrm{n}=340)$ resided in regional towns or rural areas ('regional' residents), the remainder lived in metropolitan areas ('metropolitan' residents).

Table 1. Consumers'views of farming issues in Australia $(n=1026)$

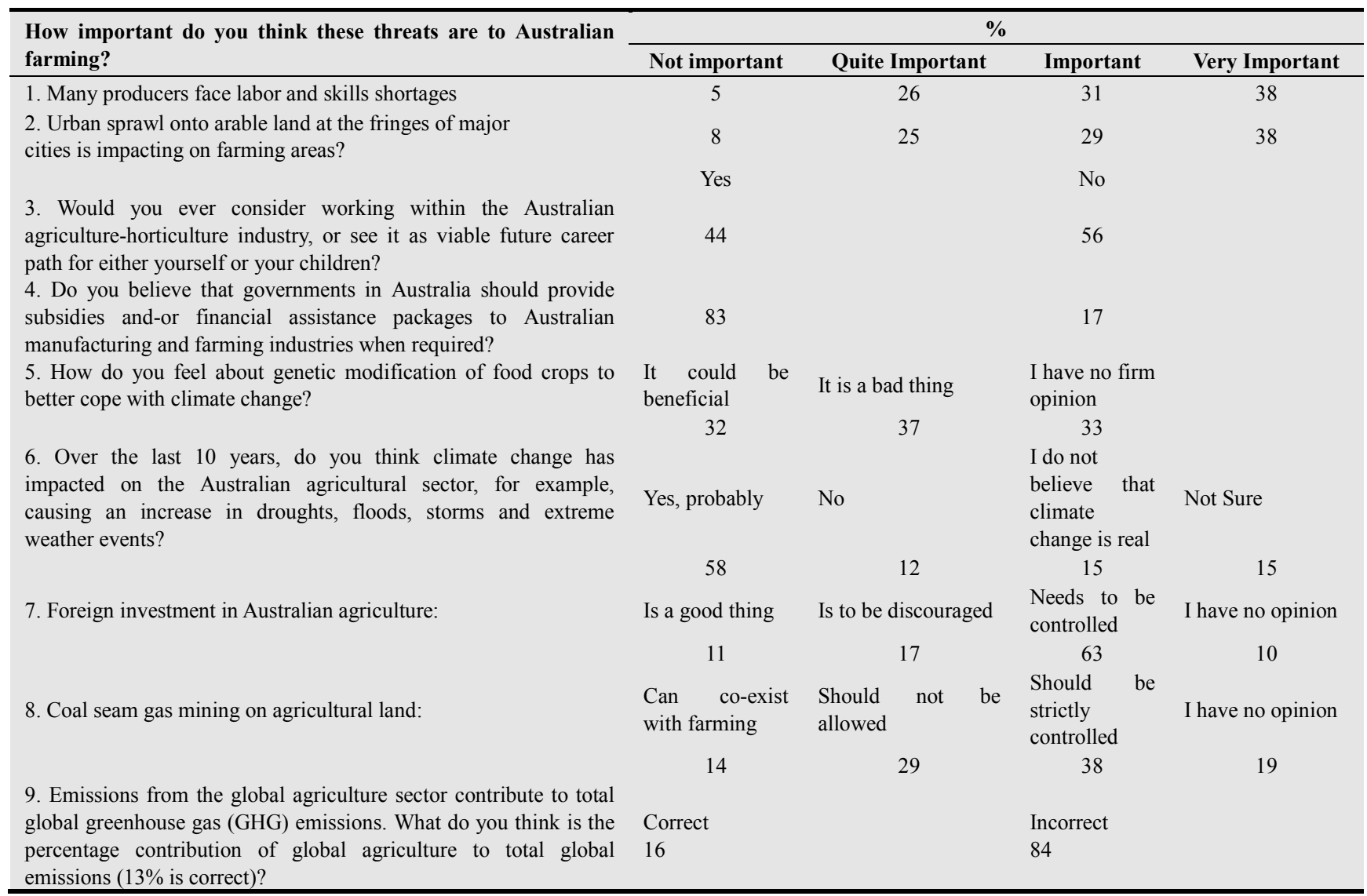

\subsection{Views of Australian Farming Issues}

Over two thirds of respondents thought labor and skills shortages and urban sprawl onto arable land were important or very important issues facing agriculture (Table 1). Four out five respondents (83\%) supported government subsidization of Australian manufacturing and farming industries. A similar proportion thought foreign investment in agriculture should be discouraged or controlled. Two thirds thought coal seam gas mining on agricultural land should not be allowed or should be strictly controlled. Opinion was more evenly split about the effects of climate change on the sector in the past 10 years: three out of five respondents indicated there probably have been effects, $10 \%$ thought not, $15 \%$ were unsure, and another $15 \%$ did not believe climate change was real. A more even split was found with respect to the genetic modification of food crops to cope with climate change: about one third thought it could be beneficial, one third thought it was a bad thing and another third had no firm opinion. Finally almost half (44\%) indicated farming might be a viable career pathway for themselves or their children.

\subsection{Farming and the Environment}

About half of the respondents (51\%) were unsure of the percentage contribution of global agriculture to GHG emissions. Around one in six $(16 \%)$ answered correctly (13\%; Table 1). More tertiary educated people could identify the percentage of GHG emissions related to global 
agriculture (13\%, Table 6).

The effects of animal and plant extinctions were taken seriously by most respondents; 4 out of 5 saw it as a tragedy, over two thirds thought it threatens our food production and threatens human survival, half thought it increased the chances of infectious diseases. Only one in five thought it had no important effects on humans (Table 2).

\subsection{Threats to Farming}

Most respondents saw excessive market control by the supermarket chains, imported food products, loss of top soil, salination and nutrient depletion of top soil as the top five threats to Australian farming (Table 3). In contrast, greenhouse gas production, long distance transport of food, animal waste in waterways, survival of native animals and hormone use in animal production, whilst important threats, were of lesser concern.

\subsection{What We Need to Address}

Most respondents thought it was important or very important that Australia should address a number of issues such as: food security, improving health and education equality and opportunities for people in regional communities and jobs creation and economic growth (Table 4). Climate change and the environment were of lesser priority.

Table 2. Respondents' views of the effects of the extinction of animal and plant species $(n=1026)$.

\begin{tabular}{|c|c|c|c|}
\hline What are the likely effects of the extinction of animal and plant species? & $\%$ No & $\%$ I don't know & $\%$ Yes \\
\hline It is a tragedy - What are the likely effects of the extinction of animal and plant species? & 7 & 13 & 80 \\
\hline It makes our food production less secure & 9 & 20 & 72 \\
\hline It is a serious threat to human survival & 13 & 20 & 67 \\
\hline It increases the chances of infectious disease epidemics in humans & 16 & 33 & 51 \\
\hline It has no important effects on humans & 63 & 18 & 19 \\
\hline
\end{tabular}

Table 3. Respondents' views of the importance of threats facing Australian agriculture $(n=1026)$

\begin{tabular}{|c|c|c|c|}
\hline How serious do you think the following threats are to agriculture in Australia? & $\begin{array}{c}\% \text { Not } \\
\text { Serious } \\
\end{array}$ & $\begin{array}{c}\text { \% Moderately } \\
\text { Serious }\end{array}$ & $\begin{array}{c}\% \text { Extremely } \\
\text { Serious } \\
\end{array}$ \\
\hline 1. Depletion of nutrients in soil & 3 & 20 & 77 \\
\hline 2. Loss of top soil & 2 & 23 & 76 \\
\hline 3. Excessive market control by supermarket chains & 5 & 20 & 75 \\
\hline 4. Salinity of soil & 3 & 24 & 73 \\
\hline 5. Fertilizer run off to rivers and sea & 4 & 24 & 71 \\
\hline 6. Imported food products & 6 & 22 & 71 \\
\hline 7. Chemical residues in meat & 6 & 24 & 70 \\
\hline 8. Hormones use in animal production & 8 & 25 & 67 \\
\hline 9. Survival of native animals & 7 & 27 & 66 \\
\hline 10. Long distance transport of food & 9 & 35 & 57 \\
\hline 11. Animal waste in waterways & 10 & 34 & 56 \\
\hline 12. Greenhouse gas production & 15 & 34 & 51 \\
\hline
\end{tabular}

Table 4. Consumers' views of issues that Australian farming needs to address in the future $(n=1026)$

\begin{tabular}{|c|c|c|c|}
\hline $\begin{array}{l}\text { How important do you think it is that Australia } \\
\text { addresses, or continues to address, the following issues: }\end{array}$ & \% Low Importance & \% Medium Importance & \% High Importance \\
\hline Climate change and-or the environment & 12 & 26 & 62 \\
\hline Food security & 2 & 18 & 80 \\
\hline Improving health and education equality & 2 & 16 & 82 \\
\hline Improving opportunities for people in regional communities & 2 & 19 & 79 \\
\hline Jobs creation and economic growth & 2 & 16 & 82 \\
\hline
\end{tabular}

\subsection{Educational and Regional Differences}

There were few differences in the ways these issues and threats were perceived by metropolitan and regional residents (Table 5). More regional people favored subsidization of farming $(87.0 \%$ vs. $80.6 \%$ metropolitan, $\mathrm{p}<0.03)$ and more of them wanted controls on coal seam 
gas mining ( $42.9 \%$ vs. $35.3 \%$. $\mathrm{p}<0.03)$.

Tertiary educated people tended to be less concerned with several issues. For example, fewer of them thought labor and skills shortages were very important; more disagreed with the subsidization of agriculture; more thought foreign investment is a good thing; and more thought coal seam gas mining can co-exist with farming (Table 6). Overall, tertiary educated people expressed less uncertainty about most issues and tended to downplay the various threats compared to the lesser educated groups.

Fewer of the tertiary educated saw the threats as being very important, compared to the other groups especially those who left high school before years 11 and 12. This underestimation applied not only to the various environmental threats but also to the greater risks of infectious disease epidemics and human survival posed by the extinction of animal and plant species

The few metropolitan - regional differences that were found related to the greater perception of the threats posed by imported food products and the greater perceived need for more education and employment opportunities in regional areas reported by regional people (Table 5).

Table 5. Statistically significant locality background differences $(n=1026)$

\begin{tabular}{|c|c|c|c|c|}
\hline \multirow{2}{*}{\multicolumn{2}{|c|}{ Item }} & \multicolumn{2}{|c|}{ Locality (\%) } & \multirow{2}{*}{$\chi^{2}(n=1026)$} \\
\hline & & City & Country & \\
\hline \multicolumn{2}{|c|}{$\begin{array}{l}\text { Do you believe that governments in Australia should provide subsidies } \\
\text { and-or financial assistance packages to Australian manufacturing and } \\
\text { farming industries when required? (\% Yes) }\end{array}$} & 80.6 & 87.9 & $8.67 * *$ \\
\hline \multicolumn{2}{|c|}{ Coal seam gas mining on agricultural land: } & & & \\
\hline \multicolumn{2}{|l|}{ Can co-exist with farming } & 14.3 & 12.1 & $13.92 * *$ \\
\hline \multicolumn{2}{|l|}{ Should not be allowed } & 28.3 & 31.5 & \\
\hline \multicolumn{2}{|l|}{ Should be strictly controlled } & 35.3 & 42.9 & \\
\hline \multicolumn{2}{|l|}{ I have no opinion } & 22.2 & 13.5 & \\
\hline \multicolumn{5}{|c|}{$\begin{array}{l}\text { How serious do you think the following threats are to } \\
\text { agriculture in Australia? }\end{array}$} \\
\hline \multirow[t]{2}{*}{ 1. Loss of top soil } & Not serious & 2.8 & .9 & $11.66 * *$ \\
\hline & Serious & 72.3 & 81.5 & \\
\hline \multirow[t]{2}{*}{ 2. Imported food products } & Not serious & 7.1 & 5 & $13.20 * *$ \\
\hline & Serious & 67.6 & 78.5 & \\
\hline
\end{tabular}

Table 6. Statistically significant Educational background differences ( $n=1026)$

\begin{tabular}{|c|c|c|c|c|c|}
\hline \multirow[b]{2}{*}{ Item } & \multicolumn{4}{|c|}{ Education (\%) } & \multirow[b]{2}{*}{$\chi^{2}(n=1026)$} \\
\hline & $\begin{array}{l}\text { Year } 11 \text { or } \\
\text { less }\end{array}$ & $\begin{array}{l}\text { Complet } \\
\text { ed year } \\
12\end{array}$ & $\begin{array}{l}\text { TAFE or } \\
\text { trade } \\
\text { qualification }\end{array}$ & $\begin{array}{l}\text { University } \\
\text { qualificatio } \\
\text { n }\end{array}$ & \\
\hline \multicolumn{6}{|l|}{ Since 1990 Australian farmers have: } \\
\hline Decreased their GHG emissions by 40 (Correct) & 4.5 & 6.4 & 3.6 & 4.3 & $34.22^{* *}$ \\
\hline \multicolumn{6}{|l|}{ How important do you think these threats are to Australian farming? } \\
\hline Many producers face labor and skills shortages (important) & 28.3 & 32.2 & 25.1 & 37.4 & $12.56^{* *}$ \\
\hline \multicolumn{6}{|l|}{$\begin{array}{l}\text { How serious do you think the following threats are to agriculture in } \\
\text { Australia? (threatening) }\end{array}$} \\
\hline Survival of native animals & 75.8 & 63.2 & 68.7 & 58.9 & $17.92^{* *}$ \\
\hline Imported food products & 79.8 & 70.2 & 76.5 & 62.3 & $25.09^{* *}$ \\
\hline $\begin{array}{l}\text { Do you believe that governments in Australia should provide } \\
\text { subsidies and-or financial assistance packages to Australian } \\
\text { manufacturing and farming industries when required? (yes) }\end{array}$ & 90.9 & 84.2 & 83.1 & 78 & $15.19^{* *}$ \\
\hline Foreign investment in Australian agriculture: & & & & & $45.18^{* *}$ \\
\hline Is a good thing & 5.1 & 9.4 & 7.5 & 19.1 & \\
\hline Is to be discouraged & 23.7 & 15.2 & 18.9 & 11.7 & \\
\hline Needs to be controlled & 60.6 & 63.2 & 64.5 & 60.9 & \\
\hline I have no opinion & 10.6 & 12.3 & 9.1 & 8.3 & \\
\hline Coal seam gas mining on agricultural land: & & & & & $28.02^{* *}$ \\
\hline Can co-exist with farming & 7.1 & 11.1 & 12.1 & 19.7 & \\
\hline Should not be allowed & 29.8 & 29.8 & 33.2 & 25.4 & \\
\hline Should be strictly controlled & 38.4 & 38 & 35.2 & 39.7 & \\
\hline I have no opinion & 24.7 & 21.1 & 19.5 & 15.1 & \\
\hline Emissions from the global agriculture sector contribute to total global & 10.6 & 9.4 & 15.3 & 22.9 & $45.46^{* *}$ \\
\hline
\end{tabular}




\begin{tabular}{|c|c|c|c|c|c|}
\hline \multirow[b]{2}{*}{ Item } & \multirow[b]{2}{*}{$\begin{array}{l}\text { Year } 11 \text { or } \\
\text { less }\end{array}$} & \multicolumn{2}{|c|}{ Education (\%) } & \multirow[b]{2}{*}{$\begin{array}{l}\text { University } \\
\text { qualificatio } \\
\text { n }\end{array}$} & \multirow[b]{2}{*}{$\chi^{2}(n=1026)$} \\
\hline & & $\begin{array}{l}\text { Complet } \\
\text { ed year } \\
12\end{array}$ & $\begin{array}{l}\text { TAFE or } \\
\text { trade } \\
\text { qualification }\end{array}$ & & \\
\hline \multicolumn{6}{|l|}{$\begin{array}{l}\text { greenhouse gas (GHG) emissions. What do you think is the } \\
\text { percentage contribution of global agriculture to total global } \\
\text { emissions? (correct) }\end{array}$} \\
\hline \multicolumn{6}{|l|}{$\begin{array}{l}\text { How important do you think it is that Australia addresses, or } \\
\text { continues to address: (important) }\end{array}$} \\
\hline Food security & 88.4 & 81.3 & 81.8 & 73.4 & $20.93 * *$ \\
\hline Improving opportunities for people in regional communities & 86.9 & 81.3 & 80.1 & 71.7 & $25.72^{* *}$ \\
\hline \multicolumn{6}{|l|}{$\begin{array}{l}\text { What are the likely effects of the extinction of animal and plant } \\
\text { species? }\end{array}$} \\
\hline It increases the chances of infectious disease epidemics in humans & 58.6 & 51.5 & 49.5 & 48.6 & $33.34^{* *}$ \\
\hline It is a serious threat to human survival & 69.7 & 69 & 67.4 & 65.1 & $18.86^{* *}$ \\
\hline It is a tragedy & 82.8 & 80.7 & 80.5 & 78.9 & $22.10^{* *}$ \\
\hline
\end{tabular}

Table 7. Fit indices of the CFA models of the predictor constructs

\begin{tabular}{lcccccccc}
\hline Predictor variables & Number of factors & $\chi^{2}$ & $d f$ & $\begin{array}{c}\text { MLR scaling } \\
\text { correction factor }\end{array}$ & $\begin{array}{c}\text { RMSEA } \\
(\mathbf{9 0 \%} \%)\end{array}$ & $\boldsymbol{C F I}$ & TLI & SRMR \\
\hline $\begin{array}{l}\text { Approval of farmers } \\
\text { role performance }\end{array}$ & 1 & 7.52 & 9 & 5.17 & $.00(.00, .03)$ & 1.00 & 1.00 & .01 \\
$\begin{array}{l}\text { Learn more about } \\
\text { agriculture }\end{array}$ & 3 & 295.90 & 116 & 1.55 & $.04(.04, .05)$ & .98 & .97 & .03 \\
$\begin{array}{l}\text { Trust source } \text { iof } \\
\text { information }\end{array}$ & 3 & 112.26 & 41 & 1.51 & $.05(.04, .06)$ & .97 & .96 & .04 \\
Universalism & 1 & 6.91 & 5 & 1.72 & $.02(.00, .05)$ & 1.00 & 1.00 & .01 \\
\hline
\end{tabular}

Table 8. Summary results of multiple regression of the threats factors

\begin{tabular}{|c|c|c|c|}
\hline Threats to soil $\left(\mathrm{R}^{2}=34.1 \%\right)$ & $\beta$ & s.e & $t$ \\
\hline Age & .01 & .00 & $5.00^{* *}$ \\
\hline Universalism & .31 & .04 & $7.17 * *$ \\
\hline Trust in external independent sources of agricultural information & .12 & .05 & $2.46^{*}$ \\
\hline Trust in retailers' information & -.13 & .03 & $-5.20 * *$ \\
\hline Approval of farmers' role performance & .23 & .05 & $4.79 * *$ \\
\hline \multicolumn{4}{|l|}{ Threats from pollution and survival native animals $\left(\mathrm{R}^{2}=30.1 \%\right)$} \\
\hline Age & .01 & .00 & $4.00^{* *}$ \\
\hline Gender & -.28 & .06 & $-4.94 * *$ \\
\hline Universalism & .30 & .05 & $6.02 * *$ \\
\hline Learning more about agriculture by spending time in farms & .15 & .06 & $2.46^{*}$ \\
\hline
\end{tabular}

Note: $\beta=$ unstandardized regression coefficient; s.e $=$ standard error; $\mathrm{t}=\mathrm{t}$ score; $* \mathrm{P}<.05,{ }^{*} * \mathrm{P}<.01$.

\subsection{Results of Multivariate Analyses of Threats and Issues}

The confirmatory factor analyses (CFA) of the "threats" items confirmed two factors, provisionally named Threats to soil (Cronbach's alpha $=0.737$ ) and Threats from pollution and survival of native animals (Cronbach's alpha $=0.793)$. The proposed two factor model fitted the data well, as indicated by non significant chi-square statistics, $\chi^{2}$ $(13)=23.30, p=.04$ with a scaling correction factor for MLR of 1.63. The other fit indices were all in the desirable range: $\mathrm{RMSEA}=.03,90 \% \mathrm{CI}(.01, .05) ; \mathrm{CFI}=.99 ; \mathrm{TLI}=.99$; $\mathrm{SRMR}=.02$. The constructs of the predictor variables were formed based on a series of CFAs (see Table 7). Inspection of Table 7 suggests that all the CFA models fitted the data well. Therefore, items measuring the same construct were summed to form the scores of each sub-domain.

The results of the multiple regression analyses of these two factors showed that perceived Threats to soil was significantly and positively related to age, universalism, farmers' role performance, and trust in external sources of agricultural information but negatively associated with trust in retailers' information (Table 8). Perceived Threats from pollution and survival of native animals were positively associated with age, universalism, and learning more about agriculture by spending time in farms but negatively related to gender (Table 8). Moreover, the variances of the two outcome variables explained by this model were reasonably high: threats from pollution and survival native animals $(30.1 \%)$ and treats to soil $(34.1 \%)$. 


\section{Discussion}

Substantial majorities of the respondents indicated that agriculture faces many threats, particularly from labor and skill shortages, climate change, urban sprawl, soil 'depletion', retailer dominance, and imported products and cautious views were held with regard to coal seam gas mining and foreign investment. These views need to be judged with regard to the widespread misconceptions about the lack of Australian ownership and unknown value of domestic production [29].

The views of the issues and threats faced by the sector appear to be independent of the public's knowledge of the issues which is low [29]. The responses to the threat items (summarized in the two threat factors) and the responses to the question about farmers' role performance, demonstrate Australian consumers' strong interest in the sector. There was strong support for the contributions of farmers on all the roles listed in the question. Possibly, these sentiments relate to the historical development of Australia and to the special place of 'the Bush' and farming in the national psyche [30]. However, they do not appear to be based on strong knowledge of current Australian agriculture [29].

So, the overall picture which emerges is of a public that knows little about farming but which at the same time sympathizes with the difficulties farmers encounter. Some of the support for farming that the respondents wished for was quite removed from current political orthodoxy such as the one in four in favor of subsidized production and the similar proportion who wanted foreign investment strongly controlled or banned and the two thirds who held similar views about coal seam gas mining. Some of these views may be based on misconceptions but they might also belong to a more nationally-oriented view of Australia which Pusey has identified in previous research [31].

These findings tend to undermine the common view that there are large differences in opinion between people who live in the regional and metropolitan parts of Australia. Whilst there were a few differences over some issues (like the importance of farming for regional employment) they tended to be small and infrequent. This is contrary to the findings of Donnelly [12] which showed a sharp contrast between primary producers' and urban consumers' views of climate change. However, the present study focused on a much wider range of environmental issues and included rural consumers, most of whom were unlikely to be primary producers.

Far more common were the education background differences. University educated respondents tended to hold firmer opinions about most issues (which were not necessarily correct) than those from less educated backgrounds (Table 7). Further, they were less concerned by extinctions of species and held more permissive attitudes towards the subsidization of agriculture, controls over foreign investment, and coal seam gas mining, than respondents from less educated groups.

Although issues like food security, regional employment, health and educational equality, supermarket chains' market dominance, and economic development were uppermost in the respondents' minds, environmental issues were also important to them. For example, greenhouse gas emissions, loss of top soil, and species losses were seen by many respondents as important issues (Table 3). That is, there was widespread pro environmental sentiment. However, familiarity of environmental terms (life cycle assessment, carbon miles, Table 3) was claimed by a minority only. Again, there may be opportunities to build on this sentiment to inform more people about these issues and industry responses to them.

The confirmatory factor analyses showed that the 'threat' items included in this survey focused on problems to do with soil and pollution and its effects. Other areas could be assessed in future surveys such as economic issues, greenhouse gas emissions, water resources and more. Overall the regression findings suggest that universalism values and two sets of informational sources influence these environmental perceptions. Universalism was the largest predictor. This suggests that the greatest understanding of the environmental issues farmers face is to be found among people who hold strong communitarian values such as peace and harmony, beauty and benevolence. We know from other studies that this consumer segment tends to support government interventions in food policies [21] support fruit and vegetable promotion polices, [26] and report eating healthier diets than others [25]. It seems a little ironic that primary producers, many of whom deny climate change [12], may gain the most support from this 'green' population segment. It might be beneficial for farmers if agricultural communications were framed for this group.

The roles of two sets of sources of agricultural knowledge in the prediction of perceived threats suggests that they do influence public opinion but in different ways. Information from independent science organizations was associated with greater awareness of threats. This suggests that information from (mainly) government and scientific bodies does influence community opinion in ways which raise their perceptions of these environmental threats. In contrast, information from retailers (whose information was trusted least of all) was trusted more by young people, and was inversely associated with perceived threats to soil. This suggests that the communication activities of supermarkets appeal more to the young and shift attention from this set of environmental problems.

Finally, it should be noted that information from peak industry organizations exhibited no associations with awareness of threats. Perhaps this is because they communicate mainly with farmers and when they communicate with the public they do not emphasize environmental issues.

\subsection{Limitations and Research Opportunities}

This research has several limitations should be borne in mind when interpreting the findings. First, the 
representativeness of the findings is provisional since the survey was administered to an on-line quota sample. Further replication is required to confirm the findings. Second, the cross-sectional design prevents the drawing of any causal relationships between variables; the findings however do suggest relationships which should be tested in further, preferably longitudinal studies. Third, only a small selection of threats and issues facing the sector were examined here; further research is required to examine other issues, particularly economic and social sustainability issues. Despite these limitations the study strongly suggests that there is considerable potential for the building of strong supportive relationships between the general population and the farming sector.

\section{Conclusions}

Most respondents, including those in urban areas, appeared to be aware of many of the issues facing Australian agriculture. Tertiary educated respondents tended to hold firmer opinions and more laissez-faire views than other respondents. Universalist values and trust in scientific information sources were key factors which predicted perceptions of threats to soil quality and the effects of pollution. The findings are relevant to current discussions about the development of agricultural policies and suggest the importance of consumer segmentation in the design and implementation of consumer communication programs.

\section{Acknowledgements}

This research was supported by a grant from Meat and Livestock Australia. The authors would like to thank Ms Veronique Droulez (MLA) and Ms Ruth Redfern (NFF) for their help and encouragement.

\section{Appendix 1.}

\section{Items used to assess consumers' perceptions of farmers' role performance}

Respondents were asked: In general how well do you think Australian farmers do the following roles? Then followed seven items: managers of the environment, contributors to Australian society, stewards of the land, carers of livestock, business operators, educated about agriculture, use technology to improve their business.

The order of presentation of the items was randomized for each respondent.

Five point rating scales were used, from 'Poorly' to 'Very Well' with an additional 'Not Sure' option.

\section{Appendix 2.}

List of twenty eight Australian sources of agricultural and environmental information
Respondents were asked: In general how much would you trust food and agricultural information provided by the following organizations? Then followed a list of 28 organizations: National Farmers Federation, State Departments of primary industries, Federal Department of Agriculture, Fisheries and Forestry, Farmers themselves, The RSPCA, Climate institute, Institute of Public Affairs, Australia Institute, Choice (Australian Consumers Organisation), ABC TV /radio rural affairs programs, Meat and Livestock Australia, Horticulture Australia Ltd, Dairy Australia, Grains Council, Woolworths, Coles, World Wildlife Fund, Australian Conservation Foundation, Newspaper reports, CSIRO scientists, University agricultural specialists, State Depts. of Health, Mining Council of Australia, Australian Food and Grocery Council, Food Standards Australia and New Zealand, Heart Foundation, Newspaper special investigations, Your local government council.

The order of presentation of the items was randomized for each respondent. Five point rating scales were used, from None to A lot with an additional 'Not Sure' option.

\section{References}

[1] DAFF (Department of Agriculture Fisheries and Forestry), "National food plan green paper 2012," Department of Agriculture Fisheries and Forestry, Canberra, 2012.

[2] A. Campbell, "Paddock to Plate: policy propositions for sustaining food \& farming systems. The future food and farm project propositions paper," Australian Conservation Foundation, 2009.

[3] J. Cary, and A. Roberts, "The limitations of environmental management systems in Australian agriculture," J Environ Manage, vol. 92, no. 3, pp. 878-885, 2011.

[4] P. Carberry, B. Keating, S. Bruce, and J. Walcott, "Technological innovation and productivity in dryland agriculture in Australia. A joint paper prepared by Australian Bureau of Agricultural and Resource Economics Bureau of Rural Sciences (ABARE-BR) and Commonwealth Scientific and Industrial Research Organisation (CSIRO)," 2010.

[5] K. Larsen, C. Ryan, and A. B. Abraham, "Sustainable and secure food systems for Victoria: what do we know? what do we need to know?", Victorian Eco-Innovation Lab, University of Melbourne, 2008.

[6] F. Vanclay, and G. Lawrence, "The environmental imperative: ecosocial concerns for Australian agriculture," Rockhampton: Central Queensland University Press, 1995.

[7] DAFF (Department of Agriculture Fisheries and Forestry), " Issues paper to inform development of a national food plan," Department of Agriculture, Fisheries and Forestry, Canberra, 2011.

[8] NSC (National Sustainability Council), "Sustainable australia report. 2013. Conversations with the future," National Sustainability Council, Canberra: DSEWPaC, 2013. 
[9] J. Parfitt, M. Barthel, and S. Macnaughton, "Food waste within food supply chains: quantification and potential for change to 2050," Philos Trans R Soc Lond B Biol Sci, vol. 365, no. 1554, pp. 3065-3081, September 2010.

[10] S. Friel, A. D. Dangour, T. Garnett et al., "Public health benefits of strategies to reduce greenhouse-gas emissions: food and agriculture," The Lancet, vol. 374, no. 9706, pp. 2016-2025, 2009.

[11] L. S. Kriflik, and H. Yeatman, "Food scares and sustainability: A consumer perspective," Health Risk Soc, vol. 7, no. 1, pp. 11-24, 2005.

[12] D. Donnelly, R. Mercer, J. Dickson and E. Wu, "Australia's farming future final market research report. understanding behaviours, attitudes and preferences relating to climate change," Report for Australian Government Department of Agriculture, Fisheries and Forestry (DAFF). Sydney: Instinct and Reason. 2009.

[13] A. Worsley, and G. Skrzypiec, "The prevalence and structure of young Australian's environmental beliefs," Global Environmental Change Glob Environ Change, vol. 8, no. 3, pp. 209-225, 1998.

[14] R. O. Herrmann, R. H. Warland, and A. Sterngold, "Nutrition concerns and food-safety concerns occur independently among adults," J Am Diet Assoc, vol. 100, no. 8, pp. 947-9, Aug 2000.

[15] S. Miles, M. Brennan, S. Kuznesof, M. Ness, C. Ritson, and L.J. Frewer, "Public worry about specific food safety issues," Br Food J, vol. 106, no. 1, pp. 9-22, 2004.

[16] A. Worsley, and V. Scott, "Exploratory studies of consumers' concerns about food and health in Australia and New Zealand," Asia Pac J Clin Nutr, vol. 9, no. 24-32, pp. 24-32., 2000 .

[17] U. K. K. Hursti, M. K. Magnusson, and A. Algers, "Swedish consumers' opinions about gene technology," Br Food J, vol. 104, no. 10/11, pp. 860-872, 2002.

[18] W. Verbeke, and J. Viaene, "Ethical challenges for livestock production: meeting consumer concerns about meat safety and animal welfare," J Agr Environ Ethic, vol. 12, no. 2, pp. $141-151,2000$.

[19] A. Worsley, "Lay people's views of school children's food services: demographic associations," Br Food J vol. 109, no. 6, pp. 429-442, 2007.
[20] R. Blasche, A. Worsley, and M. Lawrence, "Public responses to the PAN Pharmaceuticals collapse," Crit Public Health, vol. 18, no. 3, pp. 367-379, 2008.

[21] A. Worsley, "Lay people's views of school food policy options: associations with confidence, personal values and demographics," Health Educ Res, vol. 21, no. 6, pp. 848-861, 2006.

[22] S. H. Schwartz, "Universals in the content and structure of values: theoretical advances and empirical tests in 20 countries," Adv Exp Soc Psychol, vol. 25 pp. 1-65, 1992.

[23] A. Worsley, W. C. Wang, and W. Hunter, "The relationships between eating habits, smoking and alcohol consumption, and body mass index among baby boomers," Appetite, vol. 58, no. 1, pp. 74-80, Feb, 2012.

[24] W. C. Wang, A. Worsley, and E. G. Cunningham, "Social ideological influences on food consumption, physical activity and BMI," Appetite, vol. 53, no. 3, pp. 288-296, December 2009.

[25] W. C. Wang, A. Worsley, and W. Hunter, "Similar but different. health behaviour pathways differ between men and women," Appetite, vol. 58, no. 2, pp. 760-766, April 2012.

[26] A. Worsley, L. Thomson, and W. C. Wang, "Australian consumers' views of fruit and vegetable policy options," Health Promot Int, vol. 26, no. 4, pp. 397-407, 2011.

[27] L. K. Muthén, and B. O. Muthén, Mplus User's Guide, 7th ed., Los Angeles, CA: Muthén \& Muthén, 1998-2012.

[28] H. W. Marsh, "In search of golden rules: Comment on hypothesis-testing approaches to setting cutoff values for fit indexes and dangers in overgeneralizing $\mathrm{Hu}$ and Bentler's (1999) findings," Struct Equ Modeling, vol. 11, no. 3, pp. 320-341, 2004.

[29] A. Worsley, W. Wang, and S. Ridley, "Australian adults' knowledge of Australian agriculture," Br Food J, in press, 2014.

[30] H. MacKay, "The pleasing myth of egaliatarian Australia. Mitchell Oration," Adelaide Government of South Australia and Equal Opportunity Commission, 1997.

[31] M. Pusey, The Experience of Middle Australia: The Dark Side of Economic Reform. Melbourne, Vic: Cambridge University Press, 2003. 